\title{
The feasibility of energy efficiency class improving of a building from economic point
}

\author{
Daria Tarasova ${ }^{1, a}$, Kostantin Andreev $^{1}$ and Slobodan Lakić ${ }^{2}$ \\ ${ }^{1}$ St. Petersburg State Polytechnical University, 195251 Politekhnicheskaya, 29, Saint-Petersburg, Russia \\ ${ }^{2}$ Faculty of Economics, University of Montenegro, 81000 Podgorica, Montenegro
}

\begin{abstract}
In this article 4 complexes energy efficiency measures for different energy efficiency classes are chosen, it is defined the thermal heating costs of the building during the heating period, it is defined the cost and the payback period of energy efficiency measures. The conclusion about the feasibility of capital repair of buildings by increasing energy efficiency class from an economic point of view is made.
\end{abstract}

\section{Introduction}

In Russia at the present time the potential of energy savings is $35 \%$ to $45 \%$ of total modern energy consumption, which 350-460 million tons is conditional fuel. Among the reasons indicated huge potential energy saving the main are technological imperfection of fixed assets, the traditional energy squandering and mismanagement, poorly managed and do not have modern technical means consumption of energy resources, lack of standardization and certification of energy consumption, lack of application of methods of energy management [1-3].

The most effective use of energy resources of the country for the revival and subsequent recovery and provide a decent life for the population declared main goal of the energy strategy of Russia since 1995. If we consider that the Russia total area of operated buildings is about 4.8 billion $\mathrm{m} 2$ and heating annually is 400 million tons of fuel equivalent, or $25 \%$ of the annual energy countries, it is quite obvious priority role of energy efficiency measures $[4,5]$.

The efficiency of the economy is the key to sustainable economic development, preservation of the natural environment. Improving energy efficiency leads to energy savings, the cost to them. One of the possible ways of improving energy efficiency is a capital repair and modernization of existing buildings by improving energy efficiency measures $[6,7]$.

The purpose of this article is to analyze the feasibility of capital repair of buildings by improving energy efficiency class from an economic point of view.

\section{Input data}

For calculation and the analysis the building of preschool institution was taken.

Design conditions and heat energy parameters of the buildings for the climatic conditions of St. Petersburg adopted according to SNiP 23-01-99*are presented at Table 1.

\footnotetext{
${ }^{\mathrm{a}}$ Corresponding author : tarasovads@gmail.com
} 
Table 1. The design conditions.

\begin{tabular}{|c|c|c|c|}
\hline The characteristics & $\begin{array}{c}\text { Symbol } \\
\text { parameter }\end{array}$ & $\begin{array}{c}\text { Unit of } \\
\text { measure }\end{array}$ & Value \\
\hline Design temperature of inside air & $\mathrm{t}_{\text {int }}$ & ${ }^{\circ} \mathrm{C}$ & -26 \\
\hline Design temperature of outdoor air & $\mathrm{t}_{\mathrm{ext}}$ & ${ }^{\circ} \mathrm{C}$ & -0.9 \\
\hline The duration of the heating period & $\mathrm{z}$ & day/years & 239 \\
\hline Heating degree day & $\mathrm{D}_{\mathrm{d}}$ & ${ }^{\circ} \mathrm{C} \cdot$ day/years & 5473 \\
\hline Mean temperature of outdoor air & $\mathrm{t}$ & ${ }^{\circ} \mathrm{C}$ & 22 \\
\hline
\end{tabular}

Areas of external structure of building heated volume are presented at the table 2 .

Table 2. Areas of external structure.

\begin{tabular}{|c|c|}
\hline Type of structure & $\begin{array}{c}\text { Areas of structure Ai, } \\
\text { m2 }\end{array}$ \\
\hline External structure As & 807.2 \\
\hline Windows Aw & 457.8 \\
\hline Entrance external doors Ad & 50.7 \\
\hline The combined covering Ac & 1218 \\
\hline The overlapping Ao & 1186 \\
\hline The total area Atot & 3719.7 \\
\hline
\end{tabular}

Design structure of the building is presented at table 3 .

Table 3. Areas of external structure.

\begin{tabular}{|c|c|c|c|c|c|}
\hline \multirow{2}{*}{$\begin{array}{c}\text { Type of } \\
\text { structure }\end{array}$} & \multirow[b]{2}{*}{ Characteristic } & \multicolumn{4}{|c|}{ Materials } \\
\hline & & gypsum cement & slag brick & mortar & $\begin{array}{c}\text { ceramic wall } \\
\text { tile }\end{array}$ \\
\hline \multirow{2}{*}{ External structure } & $\delta, \mathrm{mm}$ & 0.005 & 0.51 & 0.02 & 0.01 \\
\hline & $\lambda,\left(\mathrm{W} / \mathrm{m} 2 \cdot{ }^{\circ} \mathrm{C}\right)$ & 0.35 & 0.58 & 0.3 & 1.7 \\
\hline \multirow{3}{*}{ Covering } & & rubberoid & mortar & foamed concrete & ferro-concrete \\
\hline & $\delta, \mathrm{mm}$ & 0.02 & 0.02 & 0.125 & 0.18 \\
\hline & $\lambda,\left(\mathrm{W} / \mathrm{m} 2 \cdot{ }^{\circ} \mathrm{C}\right)$ & 0.17 & 1.2 & 0.3 & 1.7 \\
\hline \multirow{3}{*}{ Flooring } & & linoleum & floor batts & ferro-concrete & \\
\hline & $\delta, \mathrm{mm}$ & 0.01 & 0.025 & 0.2 & \\
\hline & $\lambda,\left(\mathrm{W} / \mathrm{m} 2{ }^{\cdot \circ} \mathrm{C}\right)$ & 0.33 & 0.041 & 1.7 & \\
\hline \multirow[b]{2}{*}{ Door } & \multirow[b]{2}{*}{$\lambda,\left(\mathrm{W} / \mathrm{m} 2 \cdot{ }^{\circ} \mathrm{C}\right)$} & wood door & & & \\
\hline & & 0.26 & & & \\
\hline \multirow[b]{2}{*}{ Window } & \multirow[b]{2}{*}{$\lambda,\left(\mathrm{W} / \mathrm{m} 2 \cdot{ }^{\circ} \mathrm{C}\right)$} & triple-pane glass & & & \\
\hline & & 0.3 & & & \\
\hline
\end{tabular}

\section{Thermotechnical calculation}

By calculation we received: 
$Q_{h}=3441704.09(\mathrm{MJ})$

$Q_{\text {int }}=417390(\mathrm{MJ})$

$Q_{s}=170739(\mathrm{MJ})$

Then the amount used of energy on heating of buildings during heating season is calculated by formula 1 .

$$
\mathrm{Q}_{\mathrm{h}}^{\mathrm{y}}=\left[\mathrm{Q}_{\mathrm{h}}-\left(\mathrm{Q}_{\mathrm{int}}+\mathrm{Q}_{\mathrm{s}}\right) \cdot v \cdot \xi\right] \cdot \beta_{\mathrm{h}}
$$

$\mathrm{Q}_{\mathrm{h}}^{\mathrm{y}}=3324145.916(\mathrm{MJ})$

Then the specific drain of energy on heating of building is calculated by formula 2 .

$$
\mathrm{q}_{\mathrm{h}}^{\text {des }}=\frac{10^{3} \cdot \mathrm{Q}_{\mathrm{h}}^{\mathrm{y}}}{\mathrm{V}_{\mathrm{h}} \cdot \mathrm{D}_{\mathrm{d}}}
$$

$\mathrm{q}_{\mathrm{h}}^{\mathrm{des}}=76,76\left(\mathrm{~kJ} /\left(\mathrm{m}^{3} \cdot{ }^{o} \mathrm{C} \cdot \mathrm{day}\right)\right)$

For the two-storeyed building of preschool institution required specific drain of energy on heating of building equal to $=38 \mathrm{\kappa J} /\left(\mathrm{m} 3{ }^{\circ} \mathrm{C} \cdot\right.$ day $)$.

Then value of defection calculated specific drain of energy on heating of building from standard requirements is equal $102 \%$. It means this building corresponds to a class $\mathrm{E}$ («very low»).

\section{Improvement of building structures for the purpose of energy efficiency increase}

We modernize the building characteristics; we will improve its class of energy efficiency by the way of selection necessary energy effective measures.

Advanced building structures are chosen to improve the building characteristics to class $D$ :

- Add insulation for wall - Venti Batts, $\delta=0.1 \mathrm{~m}, \lambda=0.04$

- Add insulation for roofing - Roof Batts, $\delta=0.1 \mathrm{~m}, \lambda=0.041$

- Increase insulation for flooring - Floor Batts, $\delta=0.05 \mathrm{~m}, \lambda=0.041$

- Door is the same wood door

- Change window construction to the glass cellular block $244 \times 244 \times 98 \mathrm{~mm}, \lambda=0.33$

- Advanced building structures are chosen to improve the building characteristics to class $\mathrm{C}$ :

- Increase insulation for wall - Venti Batts, $\delta=0.2 \mathrm{~m}, \lambda=0.04$

- Increase insulation for roofing - Roof Batts, $\delta=0.2 \mathrm{~m}, \lambda=0.041$

- Increase insulation for flooring - Floor Batts, $\delta=0.1 \mathrm{~m}, \lambda=0.041$

- Change door construction to the plastic door with one chamber glass, $\lambda=0.35$

- Change window construction to the triple-pane glass in single transom of ordinary glass with $8 \mathrm{~mm}$ distance between glass panes, $\lambda=0.50$

Advanced building structures are chosen to improve the building characteristics to class $\mathrm{B}$ :

- Change the wall configuration is presented at table 4.

- Change insulation s for roofing - Polyurethane foam, $\delta=0.15 \mathrm{~m}, \lambda=0.019$

- Change insulation for flooring - Polyurethane foam, $\delta=0.15 \mathrm{~m}, \lambda=0.019$

- Change door construction to the plastic door with the triple-pane glass, $\lambda=0.49$

- Change window construction to the two one-chamber glasses in twin sashes, $\lambda=0.80$ 
Table 4. Construction of the new wall.

\begin{tabular}{|c|c|c|}
\hline Material & $\boldsymbol{\lambda},\left(\mathbf{W} / \mathbf{m} 2{ }^{\circ} \mathbf{C}\right)$ & $\boldsymbol{\delta}, \mathbf{m m}$ \\
\hline Plaster & 0.9 & 0.01 \\
\hline Gas concrete & 0.12 & 0.3 \\
\hline Polyurethane foam & 0.019 & 0.15 \\
\hline Air gaps & 0.022 & 0.05 \\
\hline Ceramic granite tile & 0.2 & 0.07 \\
\hline
\end{tabular}

\section{The technical-economic analysis}

\subsection{The calculation of thermal energy cost}

To similarly previous calculation thermal losses for each type of designs of a certain energy efficiency class were calculated and costs of the thermal energy for the heating during the heating period are defined. The costs of the construction are defined. Results are presented at Table 5.

Table 5. The annual thermal energy cost on building heating at the accounting of losses only through external enclosure structures.

\begin{tabular}{|c|c|c|}
\hline $\begin{array}{c}\text { Class of energy } \\
\text { efficiency }\end{array}$ & $\begin{array}{c}\text { Costs of the construction, } \\
\text { millions }\end{array}$ & $\begin{array}{c}\text { Cost of heating, } \\
\text { millions/year }\end{array}$ \\
\hline E & 1.32 & 1.00 \\
\hline D & 2.60 & 0.67 \\
\hline C & 4.88 & 0.49 \\
\hline B & 6.05 & 0.37 \\
\hline
\end{tabular}

The change of construction characteristic and heating cost by energy efficiency class upgrade is presented at Figure 1. As a characteristic we choose transmission factor of heat transmission (Ktr). It depends on the construction layers and determinate by Russian standards. There is obvious fact than cost of the construction directly correlated with that factor. In case of cheaper structure it will be increasing of transmission factor and, accordingly, increasing heating cost [8-11].

Total costs of heating of the building and of a design taking into account growth of tariffs for each class on energy efficiency are presented at Figure 2. The minimum values for each year show the relevance of using the energy efficiency class for each period of time. Thus, during the first three years changing of class does not entail a sum cost benefit. In the span of 3-7 years, becoming the most profitable using of Class D $[12,13]$. In considering the service life of more than 7 years it should be used a class B. 


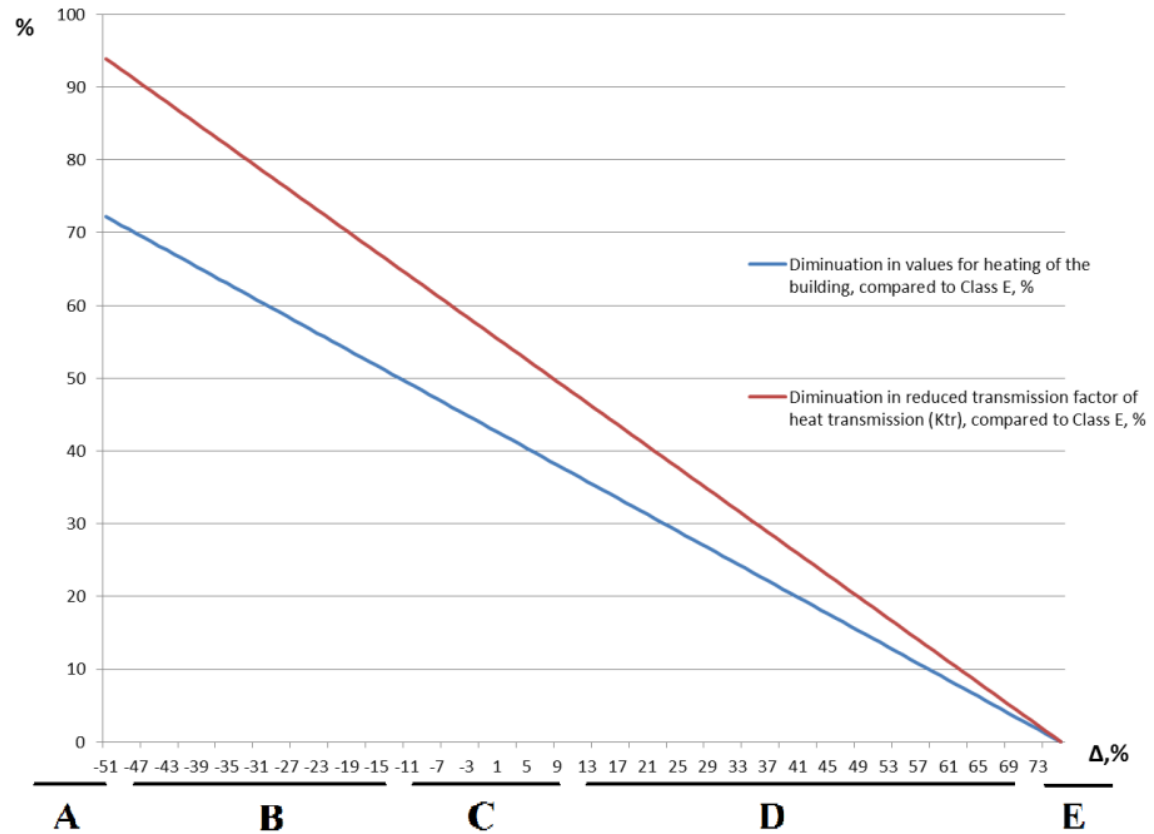

Figure 1. The schedule of change of construction characteristic and heating cost by energy efficiency class upgrade.

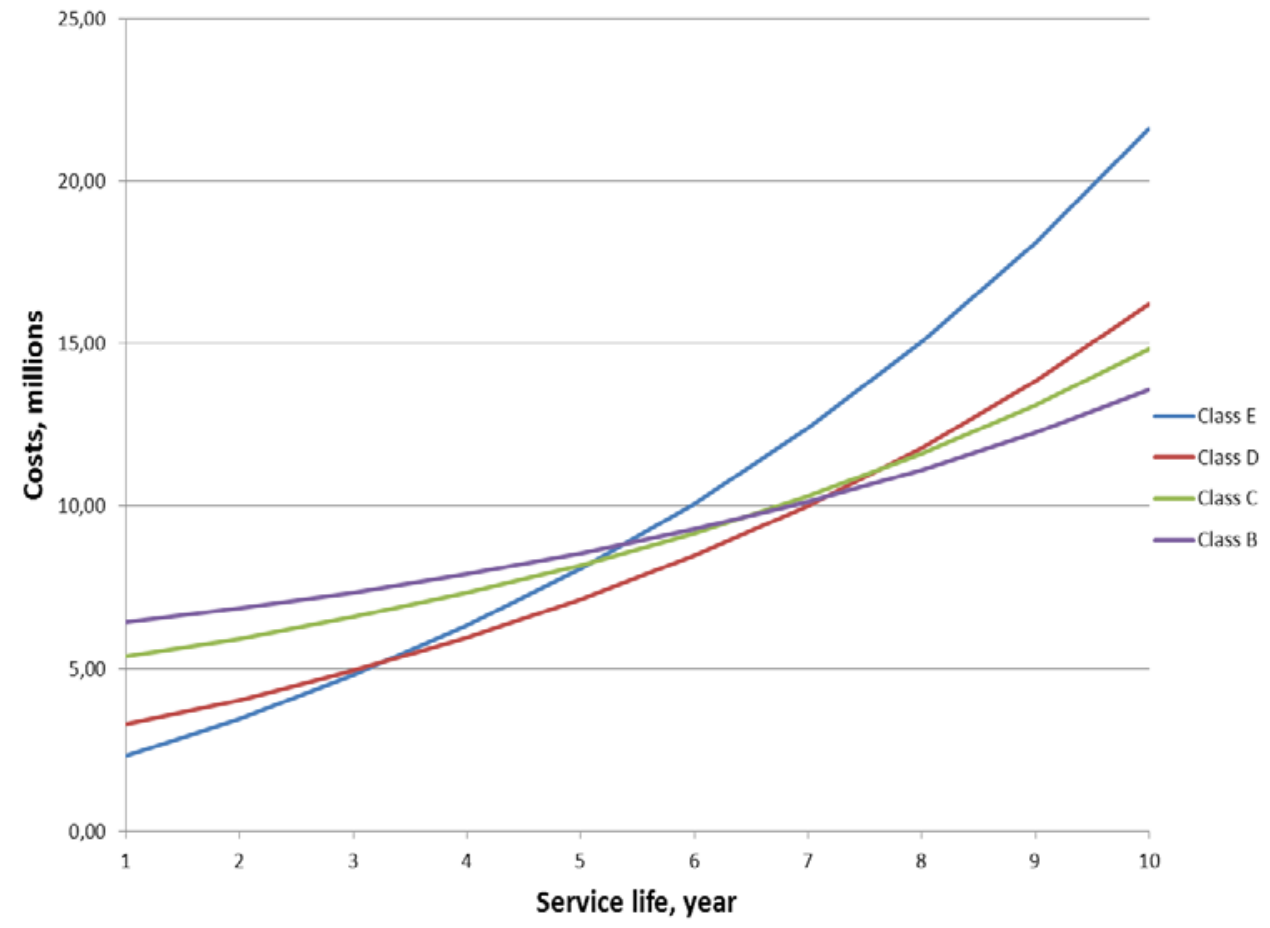

Figure 2. The dependence of total costs from service life. 


\subsection{The calculation of payback period}

We will calculate a payback period of additional costs for a structure due to economy of thermal energy [14]. Additional costs are calculated as a difference between costs of construction (class E) and construction (other class). The economy of thermal energy is a difference between costs of the thermal energy used at application of construction (class E) and construction (other class). Costs of thermal energy are expressed in millions rubles. The payback period is calculated taking into account the average annual growth of tariffs $15 \%$ a year $[15,16]$. Data for construction of a graph are presented in the Table 6 .

Table 6. The annual thermal energy cost on building heating at the accounting of losses only through external enclosure structures.

\begin{tabular}{|c|c|c|c|c|c|c|c|c|}
\hline \multirow{2}{*}{$\begin{array}{c}\text { Class of } \\
\text { energy } \\
\text { efficiency }\end{array}$} & \multicolumn{6}{|c|}{ Service life of the building, years/ Balance with accumulation, millions rub. } \\
\cline { 2 - 9 } & $\mathbf{0}$ & $\mathbf{1}$ & $\mathbf{2}$ & $\mathbf{3}$ & $\mathbf{4}$ & $\mathbf{5}$ & $\mathbf{6}$ & $\mathbf{7}$ \\
\hline $\mathrm{D}$ & 3.27 & 3.94 & 4.61 & 5.28 & 5.95 & 6.62 & 7.29 & 7.96 \\
\hline $\mathrm{C}$ & 5.37 & 5.86 & 6.35 & 6.84 & 7.33 & 7.82 & 8.31 & 8.8 \\
\hline $\mathrm{B}$ & 6.42 & 6.79 & 7.16 & 7.53 & 7.9 & 8.27 & 8.64 & 9.01 \\
\hline
\end{tabular}

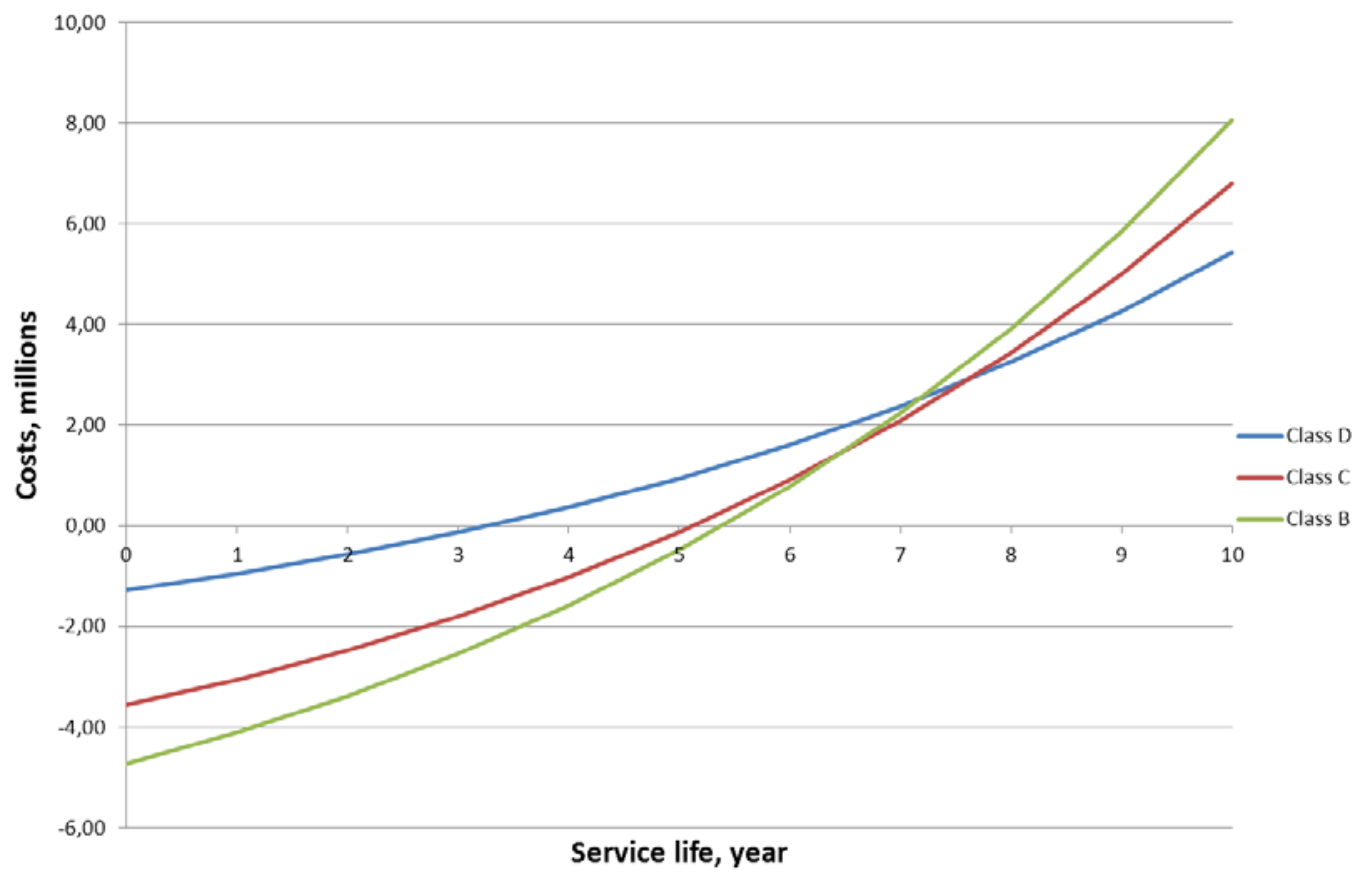

Figure 3. The schedule of payback period. 


\section{The conclusion}

The thermal energy losses through the external structures of the building with the requirements of energy efficiency class $\mathrm{C}$ will be $33 \%$ less in comparison about the building constructed according to requirements of energy efficiency class E. And thermal energy costs will increase almost twice. The thermal energy losses through the external structures of the building with the requirements of energy efficiency class $\mathrm{D}$ will be $51 \%$ less in comparison about the building constructed according to requirements of energy efficiency class E. And thermal energy costs will increase to 3.5 times. The thermal energy losses through the external structures of the building with the requirements of energy efficiency class B will be $63 \%$ less in comparison about the building constructed according to requirements of energy efficiency class E. And thermal energy costs will increase to 4.5 times.

Modernization of the building by improve of a class of energy efficiency is expedient in case of long-term investment of capital. The payback period of the modernized designs due to economy of the thermal energy spent for heating of the building during the heating period at capital repairs of the building by improvement of a class with $\mathrm{E}$ on a class $\mathrm{D}$ makes 3 years, on a class $\mathrm{C}-5$ years, on $\mathrm{B}$ class -6 years.

Using of a class $\mathrm{C}$ isn't relevance because the general costs of a class $\mathrm{C}$ aren't minimum in comparison with other classes for each year.

\section{References}

1. V. Savin, N. Savina, Gradostroitel'stvo, 1 (23), 82-84 (2013)

2. A. Avsjukevich, Construction of Unique Buildings and Structures, 2 (7), 40-54 (2013).

3. Z. Gaevskaya, X. Rakova, Advanced Materials Research, 941-944, 825-830 (2014)

4. A. Gorshkov, D.Nemova, N. Vatin, Construction of Unique Buildings and Structures, 7 (12), 49$63(2013)$

5. N. Mingottia, T. Chenvidyakarn, A.W. Woods, Energy and Buildings, 58, 237-249 (2013)

6. E Bazhenova, J. Bykova, D. Bryus, D.Tseytin, Applied Mechanics and Materials, 725-726, 1445$1456(2015)$

7. N. Lipovac, Prostor, 5 (1), 1-33 (199

8. V.V Okrepilov, M.V. Leonidovich, Asian Social Science, 11 (7), 312-325 (2015)

9. V.V Okrepilov, V.L. Makarov, A.R. Bakhtizin, S.N Kuzmina, Economy of Region, 2, 301-313 (2015)

10. V.L. Kvint, V.V Okrepilov, Herald of the Russian Academy of Sciences, 84 (3), 188-200 (2014)

11. V.V Okrepilov, V.N. Krutikov, G.I. El'kin, Measurement Techniques, 57 (2),109-116 (2014)

12. T. Zadvinskaya, A. Gorshkov, Advanced Materials Research, 953-954, 1570-1577 (2014)

13. N. Bolshakov, S. Krivoy, X. Rakova, Advanced Materials Research, 941-944, 895-900 (2014)

14. A. Kaklauskas, J. Rute, E. Zavadskas, A. Daniunas, V. Pruskus, J. Bivainis, R. Gudauskas, V. Plakys, Energy and Buildings, 50, 7-18 (2012)

15. A. Fidrikova, O. Grishina, A. Marichev, X. Rakova, Applied Mechanics and Materials, 587-589, 287-293 (2014)

16. Wilmer Pasut, Michele De Carli, Applied Thermal Engineering, 37, 267-274 (2012) 